
JHD: AINK
I-6
DEPARTINHIT OF COMIERCE

NATIOITAL BUREAU OF STAITDARDS

WASHINGTON

(Replaces Letter Circular 438)

Revised to sept. 5, 1936.
Isetter

Circular

$\mathrm{LC}-474$

\title{
SOURCES OF RADIO INFORMATION
}

\section{Contents}

1. Periodicals

2. Eooks

3. U.S. Government radio publications

4. Publications of the International Bureau of the Telecommunication Union, Berne, switzerland.

5. Radio laws and regulations

6. Safety miles.

\section{Periodicals}

The following is a partial list of periodicals largely devoted to radio. They are monthly, except where otherwise stated. A number of electrical and general magazines also publish considerable radio information.

A classified list of the articles of radio engineering interest appearing in periodicals is published each month in the British magazine listed below, Wireless Engineer. A short abstract of each article is given.

Proceedings of the Institute of Radio Engineers, 330 west 4 and Street, New York, N. Y. (Technical).

Bell system Technical Joumal. Published by Anerican Telephone and Telegraph Co., 195 Broadway, IJew York, N.Y. (Technical) (Quarterly).

QST. Published by American Radio Relay League, west Hartford, Conn. (Technical).

Radio Engineering. Bryant Davis Publishing Co., 19 . 47 th. st., New York, N.Y. (Technical). 
$10474-9 / 5 / 36$.

Electronics. McGraw-Hill Publishing Co., Inc., 330 w. 42nd st., New York, N.Y. (Technical).

Commication and Broadcast Engineering. Bryant Davis Publishing Co., 19 E. 47 th St., New York, N.Y. (Technical).

Radio News and Short-wave Radio. 461 Eighth Avenue, New York, N.Y. (semi-technical).

Radio. 7460 Beverly Blvd., Los Angeles, Calif. (Technical). Short Wave Craft. Popular Book Corp., 99-101 Hudson st., New York, N.Y. (semi-technical).

Radiocraft. Continental Publications Inc., 99 Hudson st., New York, I. Y. (Semi-technical).

General Radio Experimenter. Published by General Radio Co., 30 state street, Cambridge, Mass. (Trade, tecinical).

Radio Retailing. Published by McGraw-Hill Publishing Co., Inc., 330 N. 42nd st., New York, I..Y. (Trade).

Radio Today. Caldwell-clements Inc., 480 Lexington Ave., Netr York City. (Trade).

Wireless Engineer. Published by Iliffe \& sons, Ltd., Dorset House, stamford st., London, S. T.I, Tngland. (Technical).

Marconi Review. Marconi's Nireless Telegraph Co., Ltd., Tlectra House, Victoria, Embankment, London, Fngland. (Technicall).

Wireless Norld. Dorset House, Stamford st., London, S.E.I, England. (semi-technical) (Neekly).

Modern Jireless. Published by Amalganated Press, Itd., Fleetway House, Farringdon st., London, J.c.4, England. (Semi-technical).

E.tortrische Nachrichten-Technik. Published by Veidmannschen Buchhandlung, Berlin s.T.68, Germany. (Technical; in German).

Hochfrequenztechnik und Elektroakustik (also called Jahrbuch der Drahtlosen Telegraphie und Telephonie). Published by M. Krayn, Genthiner strasse 39, Berlin w10, Gernany. (Technical; in German).

L'Onde Electrique. Published by" Chiron, 40 rue de seine, Paris, France. (Technical; in French). 


\section{Books}

Herewith are listed a few of the many books published on the various phases of radio. Under each subject the books are in chronological order. As a matter of convenience, the prices of some of these books are given, but the Bureau can not be responsible for the accuracy of this information.

The sources of Government publications on radio are described in section 3 below.

\section{Radio Principles}

Signaling through space without wires. Sir Oliver Lodge. 1894. Electrician Publishing Co., London, England.

Electric Waves. "H. Hertz. 1900. English translation by D. E. Jones. Mackillan \& Co., 60 - 5 th Avenue, New York, N.Y.

Principles of wireless telegraphy. G. W. Pierce. 1910. McGrawHill Book Co., Inc., 330 West 4 and st., New York, $\mathbb{N}_{.} \mathrm{Y}$.

Wireless telegraphy. J. Zenneck. 1915. English translation by A. E. Seelig. McGraw-Hill Book Co., Inc., 330 West 42nd st., New York, N.Y.

The principles of electric wave telegraphy. 4th edition. J. A. Fleming. 1919. Longmans, Green \& Co., 55 Fifth Ave., New York, N.Y.

Electric oscillations and electric waves. G. W. Pierce. 1920. McGravi-Hill Book Co., Inc., 330 . 42nd st., New York, N.Y.

Modern theory and practice in radio communication. G. D. Robinson. 1920. United States Naval Institute, Annapolis, Md.

Tireless telegraphy and telephony. T. H. Eccles. 1921. Wireless Press, Ltd., London, Fngland. Also 326 Broadway, New York, N.Y.

Principles underlying radio communication. 2nd edition. 1922. Signal Corps Radio Communication Pamphlet $\mathbb{N o}$. 40. Obtainable from the Superintendent of Documents, Government Printing Office, Washington, D.C. 1.00 .

Radio telephony for amateurs. S. Ballantine. 1922. David McKay Co., Philadelpinia, Pa.

The radio manual. O. E. DunIap, Jr. 1924. Houghton-Inifflin Co., Carnbridge, Mass. 
Practical radio. Moyer and Wostrel. 1926. McGraw-Hill Book Co., Inc., 330 Hest $42 \mathrm{nd}$ st., New York, N.Y.

Fundamentals of radio. J. L. Thomes. 1927. D. Van Nostrand Co., 250 Fourth Ave., New York, N.Y. \$1.50.

Robison's manual of radio telegraphy and telephony. 1927. United states Taval Institute, Annapolis, $190 . \$ 4.00$.

Propagation of wireless waves. P. Pedersen. 1927. Vimmelskaftet, Copenhagen, Denmark.

Radio engineering principles. Lauer \& Brown. 2d edition. 1927. McGraw-Hill Book Co., Inc., 330 west 42nd st., New York, N.Y. \$3.50.

Principles of modern radio receiving. I. G. Hector. 1927. Burton Publishing Co., Bigelow Bldg., Buffalo, $\mathrm{H}_{.}$.

The outIine of radio. J. V. L. Hogan. 1928. Little, Brown \& Co., Boston, Mass.

Experimental radio. 3d edition. R. R. Ramsey. 1928. Bloomington, Ine. \$2.75.

Foundations 'of radio. R. L. Duncan. 1931. John wiley \& Sons, Inc., New York, N.Y. \$2.50.

Wiréless principles and practice. L. S. Palmer. 1928. Longmans, Green \& Co.; New York, IN.Y.'

The funderentals of radio. R. R. Ramsey. 1929. Bloomington, Ind. $\$ \bar{j} .50$.

The radio manual. G. T. Sterling. 1929. D. Van Nostrand Co., 250 Fourth Avenue, Jew'York, N.Y. $\$ 6.00$

I.C.S.Jandbook for radio operators. 1929. International Correspondence schools, scranton, Pa.

Elements of radio communication. J. H. lorecroft. 1929. John Wiley \& Sons, Inc., 440 Fourth Ave., New York, N.Y. $\$ 3.00$.

Principles of radio. Keith Henney. 1929. John Jiley \& sons, Inc., 440 Fourth Ave., New Yorik, N.Y. \$3.50.

Radiotelegraphy and telephony. Duncan and Drew. 1929. John Niley \& Sons, Inc., 440 Fourth Ave., New York, I.Y. \$7.50. 
Experimental radio engineering. JoH. Morecroft. 1931. John Wiley \& Sons; Inc., 440 Fourth Ave, liew York, N.Y. \$3.50。

The radio handbook. J. A. Moyer and J. F. Wostrel. 1931. McGraw-Hill Book Co., Inc., 330 N. 42nd st., New York, N.Y. $\$ 5.00$.

Radio elementary principles. E. E. Burns. 1932. D.. Van Nostrand Co., "New York, N. Y." \$2.00.

Communication engineering. W. I. Tverett. 1932. McGraW-Hill Book Co., Inc., 330 Vest 4 2nd st., New York, N.Y. \$5.00.

Radio engineering. F. E. Terman. 1932. MCGrar-Hill Book Co., Inc., $330 \mathrm{~m}$. 42nd st。, New York, N.Y. \$5.00.

Elementary principles of wireless telegraphy. $R$. D. Bangay. Revised by 0. F. Brown. 1933. Illffe \& Sons, Ltd., Dorset House, stamford st., London, S. ...1, England. Price 10s.6d.

Radio physics course. A. A. Gherardi. 1933. Radio Technical Publishing Co., 45 Astor Place, New York, N.Y. \$3.50. .

Principles of radio communication. J. H. Morecroft. 1934. 3d edition. John Wiley \& Sons, Inc., 440 Fourth Ave., New York, N.Y. $\$ 7.50$.

Radio engineering handbook. K. Henney. 2d ed. 1935. McGrawHill Book Co., Inc., 330 w. 42 nd St.; New York, N.Y. \$5.00.

The book of practical radio. John Scott-Taggart. 1935.

Wireless and Television Review, Cobbs Court, Broadway,

London, E.C.4, England.

Practical radio commication. A. R. Nilson and J. I. Horning. 1935. McGram-Hill Book Co., ivem York City. \$5.00.

Phenomenon in high-frequency systems. A. Hund. 1935. McGrawHill Book Co., 330 . T. 42nd St., New York, N.Y. \$6.00.

Principles of radio engineering. R. S. Glasgow. 1936. IfcGramHill Book Co., 330 W. 42nd st., New York, N.Y. \$4.00.

Foundations of wireless. A.I.M. Sowerby. 1936. Iliffe \& Sons Lta., London. $4 \mathrm{~s} .6 \mathrm{~d}$. net.

Wireless telegraphy--Notes for students. 1936. Pitman Publishing Corp., 2 . 45 th st., New York City. \$2.25. 
IC474- $9 / 5 / 36$

High Frequencies

Les ondes electriques courtes (short electric waves). R.Mesny. 1927. Les Presses Universitaires de France, 40 Boulevard Saint-Michel, Paris, France.

Short waves. C. R. Leutz and R. B. Gable. 1930. C. R. Leutz Inc., Altoona; Pa. \$3.00.

Belor 10 meters. 1932. National Co., Malden, Mass. $50 \not$.

The manual of short wave radio. 2 volumes. 1932. National Co., Malden, Mass. $50 \not$ each pamphlet.

Hoohfrequenztechnik in der Luftfahrt (High-frequency technique.

in aircraft). H. Fassbender. 1932. J. Springer, Unter den Linden; Berlin N⿴囗十, Germany, $68 \mathrm{R}$ M.

How to build and operate short wave receivers. 1933. Published by Short Wave Craft, 96-98 Park Place, New York, N.Y. $50 \phi$.

The radio amateur's handbook. A. F: Collins and G. C. B. Rowe. 7th ed. 1933. Thomas. Y. Cromell Co., 393 - 4th Ave., IJ en York, N:Y.

Short wave wireless communication. A. W. Ladner and C. R. Stoner. 1934. 22 ed. John Wiley \& Sons, Inc., 440 Fourth Ave., New York, N.Y. \$3.50.

Short wave radio handbook. C. E. Denton. Radio and Technical Publishing Co., 45 Astor Place, New York, N.Y. 1934. $\$$ I.00.

Kruse's rariophone guide. 2d ed. 1934. R. S. Kruse. PubIished R. S. Kruse, Guilford, Conn. $50 \phi$.

The radio anateurs handbook. 1936. American Radio Relay League, W. Hartford, Conn。 \$1.00.

Radio han 3 onk for enteurs and experinenters. 1936. Pacific Pub. sting Co., Palific Bldg., San Francisco, Calif.

Radio Msasurements

Prepared radio measurements with self-computing charts. Ralph Batcher. 1921. Wireless Press, Inc., 326 Broadway, New York, N.Y.

Radio-frequency measurements. E. B. Moullin. 2d ed. 1931. J. B. Lippincott, 227 South 6th st., Philadelphia, Pa. $\$ 12.50$. 
LC474 - 9/5/36.

Radio-frequency electixical measurements. H. A. Brown. 1931. McGram-Hill Book Coc, Inc, 330 W. 42nd st., New York, N. Y. $\$ 4.00$.

High-frequency measurements. A. Hund. 1933. McGram-Hill Book Co., Inc., 330 .r. 42nd st., New York, IT.Y. \$5.00.

1933 Report of the standards Committee of the Institute of Radio Engineers. Institute of Radio tingineers; 330 ग. 4?nd St., New York, N.Y.

Inductance authority (inductance charts). E。 If. Shiope. 1933.

H. Bernard, 135 Liberty st., New York, N。Y. \$?.00。

Handbook of technical instruction for wireless telegraphists. H. If。 Dowsett。 5th ed. 1934。 I],iffe \& Sons, Ltdo, Dorset House, Stainford Ști, London, S. T.I, England.

Radio receiver measurements, R. M, Bernard. 3.934. Iliffe \& Sons, Ltd., Dorset House, Stemford St, London, S. I..I,

England.

The measurenent of inductance, capacity and frequency. A. Campbell and $\mathbb{E}$, C.'Childs. 1935. Midililan \& Co., Ltd., London.

30 s. net.

Measurements in radio engineering. F. E. Terman. 1935. McGrawHill Book Co., 330 w. 42nd St., New York, N. Y. \$4.00.

Engineering handbook of the National Association of Broadcasters. J. C. Mcivary, 1936. Published by National Association of Broadcasters, National Press Bldg., Wasington, D.C. \$10.00。

Vacuurn Tubes

The thermionic vacuum tube and its application. H. J. Van der Bijl. 1920. McGraw-Hill Book Co., Inc., 330 T. 4 2nd st., New York, N.Y. \$5.00。

Thermionic tubes in radio telegraphy and telephony. John scottTaggart. 1921. vireless Press, Itd., London, England. Also 326 Broadway, New York, N. Y.

Elementary textbook on wireless vacuum tubes. John scott-Taggart. 1922. Tireless Press, Ltd., London, England. Also 326 Broadway, New York, N.Y.

Theory of thermionic vacuum tube circuits. I. J. Peters. 1927. McGraw-Hill Book Co., Inc., $330^{\circ}$. 42nd st., New York, N.Y. 
I $0474-9 / 5 / 36$

Flectron tubes and their appication. J. H. Morecroft. 1933. John Wiley \& Sọn, Inc., 4 il Fourth Ave, New York, N.Y. .$\$ 4.50$.

Theory of thermionic vecuum tubes. E。 I. Chaffee. 1933. IncGrawHill Book Co., Inc。, 330 \%. 42nd sto, New York, N.Y. $\$ 6.00$ 。

Electronics, R. G. Hudson, 1933. John Wiley \& sons, Inc.,

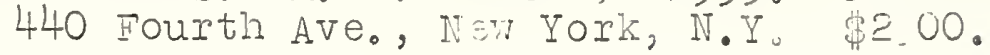

Electron tubes in industry, Ko Henner, 1934. McGraw-Hill Book Co, Inc。, 330 T! 4 2nd St, Ne York, N.Y. \$5.00.

Electrons at work, Co R. Underhill. 1934. McGran-Hill Book Co。, Inc, 330 \%. 4 2nd st., IN er York, N.Y. $\$ 3,00$ 。

The physics of electron tubes. Io R. Koller. I934。 IroGrawHi... Book Co, Inc, 330 . 4 2nd st, New York, N.Y. \$3.00.

Thermionic emission. A. I. Reiman. 1934. John viley \& sons, Inc., 440 Fourth Are., Ter Yorr, NoY. \$5.50.

Industrial electronics. F. F. Gulliksen \& $\Xi$. H. Vedder. 1935. John wiley \& sons, Inc, 440 Fourth Ave., Nev Iork, IN.Y. $\$ 3.50$.

Photoelectric Phenomena

Photocelis and their applications. Zworykin and Tilson. 1932. $2 d$ ed. John I.Y. $\$ 2.50$.

photoelectric phenomena. A. I. Hughes and I. A. Du Bridge. 1933. MoGram-Hill Book Co., Inc., 330 i. 4 2nd st., INew York, N. Y. $\$ 5.00$.

Photoelectric cells; their properties, use and applications. N. R. Campbell and Dorotiny Ritchie. Sir I. P.itman \& Sons, Ltd., IN Y York, N.Y. 3d ed. 1934. \$3.75.

Photoelectric cell applications. R. C. valker and T. M. C. Lance. 2nd ed. 1935. Pitman Publishing Corp., 2 "iest 45 th St., Nert York, N.Y. \$2.50。

Television

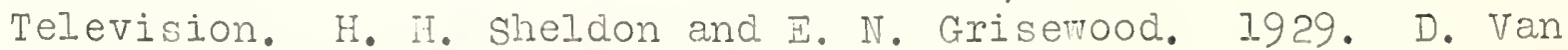
. Nostrand Co., IT Tri York, I. Y. \$2.75.

Television -. Its methods and uses. ت. H. Felix. 1932. McGrawHill Bools Co., Inc., 330 T. 4 2nd st., Ner Yorli, N. $\mathbb{N}_{\text {. }}$ 2.50. 
First principles of television. A. Dinsdale. 1932. John viley \& Sons, Inc, , 440 Furth Ave., New York, N.Y. \$3.50.

The outlook for television. O. E. Dunlap. 1932. Harper \& Bros., 15 E. 26tin st。, Ijew YorK, N.Y.\$4.00。

Television - Today and tomorrow. S. A. Moseley and H. J. BartonChapple. 1934. Sir Iseac Pitman \& Sons, Itd., London, England.

Television, theory and practice. J. H. Rayner. 1934. Chapman and Hall, London. I2s.6a.

Television (Collected addresses and papers on the future of the new art and its recent technical developments), vol. I, July 1936, RCA Institute's Technical Press, 75 Varick st., New York City.

\section{Servioing Radio Rouipment}

Servicing avto-radio receivers. J. F. Rider. Redio Treatise Co., Inc。, 1440 Broadray, IT Y York, N.Y.

Radio service questions and answers. J. F. Rider. 2 volumes. Redio Treatise Co, Inc, 1440 Broadway, New York, N.Y.

Practical radio repairing hints. J. F. Rider. Radio Treatise Co., Inc., I440 Broadway, Tew York, $N . Y$.

Practical testing systems. J. F. Rider. 1930. Radio Treatise Co., Inc, 1440 Broadway, New York, N.Y. \$1.00.

Radio servicing course. A. A. Gherardi and B. M. Freed. 1930. Radio Technical Pub. Co., 45 Astor Place, New York, N.Y. $\$ 1.50$.

Servicing receivers by means of resistance measurenents. J. F. Rider. 1932. Radio Treatise Co., Inc., 1440 Broadway, New York, N.Y.

Servicing superheterodynes. J. F. Rider. Revised edition 1934. Radio Treatise Co., Inc.; 1440 Broadway, New York, N.Y.

Specialized auto radio manual. Vol.I. J.F.Rider. 1933.

Radio Treatise Co., Inc, 1440 Broadway, INew York, N. Y. $\$ 3.50$ 。

Practical radio construction and repairing - Radio receiving tubes - Practical radio - All. three of these books by lloyer and wostrel. 1934. Published by McGrarm Hill Bool Co., Inc., 330 H. 42nd St., New York, N.Y. Price for three, $\$ 7.50$. 
$2 \mathrm{C} 474-9 / 5 / 36$

Perpetual trouble shooter's manuel. J. F. Rider. 6 volunes. 1935. Radio Treatise Co, Inc., 140 Broadraj, Ner York,

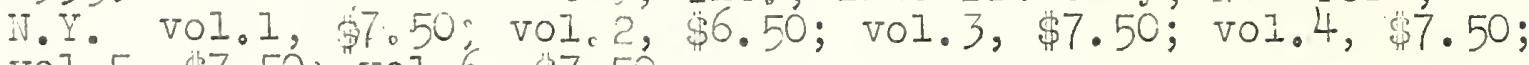
v01.5, \$7.50; v01.6, \$7.50.

Official radio service mamu.1. 1931, \$4.50; 193?, \$5.00; 1933 , $\$ 5.00 ; 1934, \$ 3.50 ; 1935, \$ 7.00$. Garnsback Publications Inc., 99 Hudson street, IN Tork City.

Auto-radio service nonual and suppleinent. 1936. \$2.50. Gernsback Pubilcations inc。, 99 Hudson ist, liew York City.

Tireless ervicing manual. W. T. Cocking. 1936. Iliffe \& sons, Ita., Jondon, England. 5s, net.

\section{Misce? I aneous}

How to pass U.S.Govemment radin license ezaminations. John Wiley \& Sons, Inc。, 440 Fourth Ave., Ner Yoris, N.Y. \$2.00.

Radio traffic manul and operating regulations. Duncan \& Drew. John Wiley \& Sons, Inc., 440 Fourth Ave., New York, N.Y. $\$ ? .00$.

UsefuI radio tables. J. F. Rider. Radio Treatise Co., Inc., 1440 Broadway, New. York, N.Y.

Wireless direction findirig and directional recention. $2 d$ ed. R. Keen. 1927. IIiffe \& Sons, Ltd., Dorset House, Stanford St., London, England.

Mlectrical condensers。 P. R. Coursej。 1927. Sir I. Pitman \& Sons, Ltd., London, Englano.

Radio data charts. R. T. Beatty. 1930. Iliffe \& sons, Ltd., Dorset House, Stanford st., Juondon, S. I.I, gnglend.

Quarta resonators and osciliators. P. Vigoureux. 1931. obtainable from British Inibrary of Information, French Buildings, East 45 th st。, New York, IT. $T$.

High-frequency alternating currents. K. McIlwain and J. G. Brainard. 1931. John wiley \& Sons, Ino., 440 Fourth Ave., New York, N.Y. \$6.00.

Radio operating questions and answers. 5tin ed. 1933. Nilson \& Horning. IfCGrew-Hill Book Co., Inc., 330 T. 42nd st., iver York, N.Y. \$2.50. 
The cathode-ray oscillograph in radio research, R. A. TatsonWatt, J. F. Herd, I. H. Feinuridge-Bell. 1933. Publisied by H.M. Stationery office, London, England. Obtainable from British Library of Information, French Buildings, East $45 t i$ st., Iew York, NoY。

Applied acoustics. H. Folsom and F. Inassa, 1934. P. Blakeston's stone \& Coc, Inc, 101? WaInut St, Philadelphia, Pa. $\$ 4.50$.

Broadcast receiver design。G. So Groner. 1934. Manson Pub-

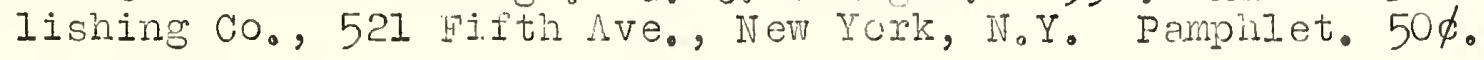

All-wave receiver design. C.. S. Graiger. 1934. Manson PubIishing Co, 521 Fifth Ave., ITew York, N.Y. Pamphlet. $50 \phi$.

High-idelity receiver design. G. S. Granger. 1934. Manson Prulishing Co, 52. Fifth Ave., New York, N.Y. Pamphlet。 506.

Flectric circuits and vave filters. A. T. Starr. 1935. Pitman Publishine Carp., 2 . 45th st., New York City. 6.00 .

The cathode-ray tube at pork. J. F. Rider. 1935. J. F. Izider, Publisher, 1440 Broadway, New York City. \$2.50.

Making a living in radio. Zeh Bouck. 1935. McGrati-Hill Book Co., 330 w. 4 2nd st., Now York City. \$2.00.

\section{U. S. Government Radio Publications}

A large number of papers on radio subjects have been issued by the National Bureau of standards. Some of these have been published by the Government Pinting office and some in various periodicals. Most of them are of interest primarily to the radio engineer or scientist. A list of the current radio publications can be secured by addressing a request to the jational Bureau of standards, Washington, D.C. News of the Bureau's radio work, and announcements of new publications, are given in "Technical News Bulletin", a monthly publication whicin nay be obtained by mail in the $U$. S. for 50 cents per year from the superintendent of Documents, Government Printing office. The notices of new publications state the prices at wich each may be purchased from the superintendent of Documents. The publications of the National Bureau of stanuards cover many subjects, including, besides radio, electricity, light, sound, ileat, chemistry, metaliurgy, engineering.materials, standards of veight and measure, and many other scientific and techilical subjects.

A pampilet, "Radio broadcast stations of the United states" (published by the Federal Communications Commission) may be ob- 
tained for 10 cents from the superintendent of Documents, Government Printing Office, washington, D.C.

A book, "Internetional Radiotelegrapin conference, Iradrid, 1932", giving the International Telecommunication Convention and Radio Regulations (puivished by the state Dept.) may be obtained for 30 cents from the superintendent of Docurnents, Government Printing Office, Washington, D.C.

\section{Pulsications of International reau of the Telecon- munication Union, Eernis Switzerland.}

The following radio station lists are available from the International Bureai, at tie prices stated.

List of fremencies, and supplements. ( 26 swiss gold francs, incluing posta,e).

List of coast stations end ship stations. (3.70 swiss gold francs, including postace).

List of aircraft and aeronavical stations. (2.50 SWiss gold francs, including postage).

List of broadcasting stations, and supplements. $\quad(4.00$ swiss gold francs, including postage).

List of stations performing special services, and supplements. ( 5.50 swiss gold francs, including postage).

List of call letters of fixed, land, and nobile stations. and supplements. ( 9.70 swiss gold francs, including postage).

List of Fized stations. $\quad(7.70$ sisiss gold francs, including postage).

Remittance should be made by international money order to the International Bureau of the Telecommication Union, Berne, Switzerland.

\section{Radio Laws and Regulations}

The radio regulations and laws of the U.S. are given in a publication entitled. "Revised rules and regulations of the Federal Radio commission," copies of which are obtainable from the Superintendent of Documents, Govermment Printing Office, Washington, D.C., for 45 cents. This is a loose-leaf pamphlet; changes in regulations are added from time to time. 
The law provides that in order to operate a radio traismitting station, both a stiation license and an operator license must be secured. The law piovides severe penalties for the operation of a transitting station without proper licenses.

A station used oily for receiving does not require a station license. operators oi stations used only for receiving do not require operatorsl Iicenses, but must maintain secrecy in regard to messages heard, other than broadcast messages.

Information and tire necessary appication blanks for station and operators 1 senses are obtailable from the Federal Communications Comission, Tashington, D.C., or the field office of the commision in the district in which the applicant resides.

Redio District No.1,- (Includes: Connecticut, Majie, llassachusetts, New Henshire, Riode I land and Vesmont). Acdress: Inspector in Charge, Federal Commuications Comission, Customhouse, 7 th Floor, Bostch, Mass.

Radio District No. 2. - (Includes: The Counties of Albany, Bronx, Columbia, Delavare, Dutchess, Greene, Kings, Nassau, Orange, Nev York, Putnan, Queens, Rensselaer, Richrond, Rockland, Schenectady, Suffolk, Sullivan, Ulster, and Testchester of the state of $N$ tew York, and the Counties of Bergen, Fssex, Hudson, Hunterdon, Mercer, Middlesex, Monmouth, Moris, Passaic, somerset, sussex, Union and llarren of the state of Miew Jersey). Adaress: Inspector in Charge, Federal communications commission, $1024-1026-1030$ Federal EIds., 641 Washington st., New York, N. I.

Radio District No. 30- (Includes: Adans, Berls, Bucks, Carbon, Chester, Cumberlaid, Dauphin, Delaware, Lancaster, Lebanon, Lehigin, Monroe, Montgomery, Nortiampton, Perry, Philadelphia, Schuylkill, and York of the state of Pennsylvania, and the counties of Atlantic, Burlington, Canden, cape llay, Cumberland, Gloucester, ocean, and salem of the state of New Jersey; and the County of Nevcastie, state of Delavare). Address: Inspector in Charge, Federal Communications Comission, Room 1200, Nev U.S. Customhouse, 2nd and Chestnut sts., Philadelpila, Pa.

Radio District No.4.- (Includes: The state of Maryland, the District of columbia, and the counties of Arlington, clark, Fairfax, Fauquer, Frecerick, Loudoun, Page, Prince viliiam, Rapjahainock, Shenandoah, and Tarren of the state of Virginia, and the counties of Kent and Sussex, of the state of Delaware). Address: Inspector in Charge, Federal Communications Commission, Fort McHenry, Baltimore, Md.

Radio District No. 50- (Includes: The state of Virginia, except the counties of Arlington, clark, Fairfax, Fauquier, Frederick, Loudoun, Paçe, Prince viliiam, Rappahannock, shenandoah, and Warren; and the state of North Carolina except the counties of Ashe, Avery, Buncombe, Burke, Caldwell, Cherokee, clay, cleveland, 
Graharn, Haymood, Henderson, Jachon, InDortl, Macon, Iladison, litchell, Polk, Rutiezford, Strain, Transylvania, Tatauga and Yancy). Aduress: Instector in Charge, Federal Comunications Comission, Room 402, Jew post Ozice Euilding, Iorfolk, Va.

Redio District ito, 6.- (Incilides: The states of Alabama, Georgia, South Cerolina, Fennessee, and the connties of Ashe, Avery, Buncombe, Burke, Caldnell, Cherokee, Clar, Cleveland, Graham, Haytood, Henderson, Jac'oon, McDovell, Mcon, Wadison, Mitchell, Polk, Rutherford, Swair, Trensylvani. Tatauga and Yancy of the State of Nortin Carolina. Acioress: Inspector in Charge, Fecleral Comunicaticns Comission, HI ITet Post Office BIdg。, Atlanta, Ga。

Radio District No. 7.- (Includes: The state of Florida, Puerto Rico, and Virgin Isles) Acldess: Inspector in Charge, Federal Communications Comission, Post Office Box 150, Iniani, Fla.

Redio District 100 8.-. (Incluaes: The states of Arkansas, Louidama, ississip, and the Gity or Texarkana only of Texas). Address: Inspector in Charge, Federal Commications Commission, 326 Customiouse, ien onIeans, Ia.

Redio District iTo, 9- (Includes: The Counties of Aransas, Brazoria, Brocrs, calhoun, Caneron, Chambers, Fort Bend, Galveston, Goliad, Farris, Hidalgo, Jackson, Jefferson, Jin "elis, Kenedy, Yleberg, Inantagoria, IJueces, Refugio, San Patricio, Victoria, Tharton, and Nillacy of the state of Texas'. Address: Inspector in Charge, Federal Comunications comissiun, 209 Prudential Building, Galveston, Texas.

Radio District To. 10.- (Includes: The state of Texas, except the Counties of Aransas, Brazoria, Brooks, Calhoun, Cameron, Chambers, Fort Bond, Galveston, Goliad, Harris, Hidalgo, Jackson, Jefferson, Jin Tells, Kened\%, Kleberg, Iatagorá, Nueces, Refugio, San Patricio, Victoria, Tharton, and Yancy, and the City of Texarkana, and the states of Ter Merico and Oklahoma). Address: Inspector in Chrrge, Federal. Communications Comission, 464 Fecierai Eldgo, Dalizas, Iex.

Radio District ilo. 1I.- (IncIudes: The state of tevada, Arizona, and the counties of Imperial, Kern, Kings, Los Angeles, lionterey, Orange, Riverside, Sn Bemerdino, san Diego, San Luis obispo, Santa Barbara, Tulare, and Ventura of the State of CaIifornia). Address: Inspector in Charge, Federal Communications comrission, l105 Rives-Strong Bldg., Los Angeles, Calif.

Radio District INo. 12- (Includes: the state of california, except the counties of Imperial, Kern, Kings, Los Angeles, Inonterey, Orange, Riverside, San Bernardino, san Diego, San Luis obispo, Sante Barbara, Tulare, and Ventura; and the state of 
Nevada, except the ccunty of clcrk, Guam, lidway, and American Samoa). Adciress: Inspector in Charge, Federal dommunications Comission, 328 Custorbouse, san Francisco, Calif.

Redio District IO $_{0} 13$ - (Includes: the state of Oregon and the state of Idaho, except the Counties of Benewain, Bonner, Bowndary, clearvater, Idaho, Tootenai, Latah, Lewis, Nez Perce, and shoshone). Adaress: Inspector in Charge, Federal communications Commission, $207 \mathrm{New}$ U. S. Courthouse, Pcirtland, Oregon.

Radio District Io, $1 !_{0}-$ (Includes: A7.ska; the state of vashington, the counties of $\bar{B} \in$ evein, Bonner, Boundary, Gleamater, Idaho, Kootenai, Latah, Ievis, Nez Perce, and Shoshone of tire state of Idaho, and the Counties of Beaverhead, Broadwater, Cascade, Deerlodge, Flathesd, Gallatin, Glacier, Granite, Jefferson, Lake, Lewis and Clark, Iincoln, Medison, Mezgher, Mineral, Missoula, Pondsis, Powell, Favili, scinders, Silver Bow, leton, and Toole of the state of Isontana. Address: Inspector in charge, Fecieral Comminications Commission, sos Feceral Office BIdg., seattle, Wash。

Radio District Io, 15,- (Includes: The states of Colorado, Utah, Wyoming, and Montana, except the Counties of Beaverhead, Broadwater, Cascade, Deerioage, Flathead, Gollatin, Glacier, Granite, Jefferson, Lake, Lewis and Clark, Lincoln, Madison, Meagher, Mineral, Missoula, Ponders, Powell, Ravalii, Sanders, silver Bon, Teton, cnd Toole). Address: Inspector in Charge, Federal Communications Commission, 538 Customhouse, Denver, colo.

Radio District No. 16.- (Includes: The States of Norti Dakota, Souti Dakota, Minnesota, and the Counties of Alger, Baraga, Chippewa, Delta, Dickinson, Gogebic, Houghton, Iron Keeweenaw, Luce, Mackinac, Marquette, Menominee, Ontonagon, and schoolcraft of the state of lichisan, and tire state of wisconsin, except the counties of Columpia, Craviord, Dane, Dodge, Grant, Green, Iowa, Jefferson, Konosha, Lafayette, Milwauke, Ozaukee, Racine, Richland, Rock, Sauk, Walworth, Wasington, and Waukesha). Address: Inspector in Charge, Federal communications Commission, 927 ivew Ilain Post office Bldg, st. Baul, Minn。

Radio District No. 17.- (Includes: the states of vebraska, Kansas, Missouri, and Iowa, except the Counties of Allamakee, Buchanan, Cedar, clayton, clinton, Delaware, Des Moines, Dubuque, Fayette, Henry, Jackson, Johnson, Jones, Lee, Innn, Louisa, Muscatine, scott, washington, and innesliek). Address: Inspector in charge, Federal comunioations commission, 410 Federal Bujlding, Kansas city, 
Radio District Ijo. 3. - (Includes: the stotes of Indiana, IIIinois, and the counties of Allarnakee, Buchanan, Cedar, Clayton, Clinton, Delaware, Des Moires, Lubucve, Fayette, Henry, Jackson, Johnson, Jones, Lee, Iinn, Louisa, lifrscatine, scott, Washington, and vinneshiek of tile state op Iora; and the counties of columbia, Crawford, Dane, Dodge, Grant, Gieen, Iora, Jefferson, Kenosha, Lafayette, Milwaukee, Ozaukee, Racine, Richland, Rock, Sauk, Walworth, "ashington and Taukeshe, of the state of Tisconsin). Address: Inspector 'i. Chare, Federa?. Communications Commission, 2022 Engineering Sldg, Chicago, Ill.

Radio District $300,192-$ (Includes: The state of Hichigan, except the counties of Alger, Baraga, Chippewa, Delta, Dickinson, Gogebic, Houghton, Iron, Keweenar, Iuce, Mackinec, Marquette, Ifenominea, Ontonacon and Schoolcraft; the states of Ohio, Kentucky, and West Virginia). Address: inspector 'r Charge, Federal Commuitications Comission, 1025 New Federal Blds, Detroit, Mich.

Radio District No, 20- (Includes: the state of New York, except the counties of AIbany, B:onx, Columioia, Delaware, Dutchess, Greene, Kings, Jessai, New Yoris, Orange, Putnam, Queens, Rensselaer, Richmond, Rockland, schenectady, Suffolk, Sullivan, Ulster, and Testchester; the state of pennivivania, except Adams, Berks, Bucks, Carbon, Chester, Cumberland, Dauphin, Jelaware, Lancaster, Lebanon, Lehigh, Monroe, irontgomery, Iortiampton, Perry, Philadelphia, Schuylkill, and York). Address: Inspector in Charge, Federal Communications Commissicn, 514 Federal Bldg。, Buffalo, $\mathbb{N} . Y$.

Radio District No. 21.- (Includes Territory of Hawaii). Address: Inspector in Charge, Federal Commications Comission, Aloha Tower, Fonolulu, T.H.

The Commission also has tire two following field offices: Inspector in Charge, Federal commications Commission, central Frequency Monitoring station, P. O. Box 78s, Grand Island, Neb.; Inspector in Charge, Federal Comminications Commission, Naval Training station, Radio station Bldg., Great Lakes, III.

Gxaminations for radio operators: licenses are held in the district offices listed above and in addition at:

Washington, D.C.

Sclienectady, N.Y. "Tinston-Salem, N. C. iveshville, Tenn。
San Antonio, Tex. Oklahome City, Okla. Des linoines, Iowa. St. Louis; Mo.
Pittsburgh, Pa. Clevel.and, Ohio Cincinnati, Ohio columbus, Ohio. 


\section{Safety Ruies}

All ordinary precautions required for the safe operation of any electrical equipment should be observed in every radio station; for example, all highwoltage wiring should be carefuliy insulated and kept as far as possible from other wiring and so placed a,s to mininize the possibility that persons may come in contact with it, and suiteljJe danser tass should be displayed.

Insurance companies and city govemments make certain requirements regarding electrical installations in buildings. The usual requirenents axe summarized in a small book, the jo,tional Electrical code, which may be secured for ten cents from the National Board of Fire Underwiters, 85 John street, New York, N.Y. Article 37 of this code gives the requirements for radio equipment.

Fequirenents for safe radio construction are given in National Bureau of strindres Handbook H9, "Cafety Rules for Radio Installations, "wich may be obtained from the superintendent of Documents, Government Printing office, Wrsington, D.C., at ten cents per copy. Plis handbook gives, on pages 7 to 14, rules for erection of antennas. Sorne explanation of these rules and of the reasoins for them is given in part 5 of the iv. B, s. Handbook H4, "Discussion of the National Electrical safety code," the price of which is $\$ 1.00$.

Safety standards for radio transmitting equibrent are given in the Report of the standards committee, obtainable from the Institute of Radio Engineers, 330 West 42nd St., INew Yorr, N.Y.

Departinent of Commerce, Washington, D.C. 
